\title{
TINGKAT PENGETAHUAN MAHASISWA FAKULTAS EKONOMI UNIVERSITAS ADVENT INDONESIA TENTANG PENCEGAHAN DAN PENULARAN COVID-19 DI ASRAMA PUTRA
}

\author{
Frederickh Halomoan Simaremare, Novita Verayanti Manalu \\ Keperawatan S1, Fakultas ilmu keperawatan, Universitas Advent Indonesia, Jl. Kolonel Masturi No.288,
} Cihanjuang Rahayu, Kec. Parongpong, Kabupaten Bandung Barat, Jawa Barat 40559, Indonesia

E-mail:frederiksimaremare@gmail.com

\begin{abstract}
Article Title. Corona Virus Disease is an infectious disease caused by a new type of Corona Virus that was discovered in 2019. The purpose of this study is to find out the knowledge and attitudes of students about the prevention of Corona Virus Disease in Indonesia.. This study uses a correlative research method to determine the relationship between variables without affecting and manipulating the variables. Sampling was 96 students. This research instrument using a questionnaire via google form. Asimp. Sig value 0.743>0.05 So it can be concluded that "There is no significant relationship between the level of student knowledge and preventive behavior." It can also be concluded that the level of knowledge about COVID-19 does not have correlation with prevention and transmission behavior. The conclusion of this study is the level of knowledge of economics faculty students about the prevention and transmission of Corona Virus in the male dormitory of 96 respondents who are in the high category. Students understand how to prevent transmission of the Corona Virus Disease. This condition is a good potential and strength for the government in handling the Corona Disease Virus program. However, various parties must continue to make efforts to prevent and warn against the spread of Corona Virus Disease so that there is no increase in the number of serious cases.
\end{abstract}

Keywords: COVID-19, Youth, Knowledge, Prevention

\begin{abstract}
Abstrak
Corona Virus Disease adalah penyakit infeksi yang disebabkan oleh Corona Virus jenis baru yang ditemukan pada tahun 2019. Tujuan penelitian ini yaitu untuk mengetahui pengetahuan dan sikap mahasiswa tentang pencegahan Corona Virus Disease Di Indonesia. Penelitian ini menggunakan metode penelitian korelatif. Untuk mengetahui hubungan antara variabel tanpa mempengaruhi dan memanipulasi variabel. Pengambilan sampel sebanyak 96 mahasiswa. Instrument penelitian ini menggunakan kuesioner melalui google form.Nilai Asimp.Sig 0,743 > 0,05 Maka dapat disimpulkan bahwa "Tidak terdapat hubungan yang signifikan antara Tingkat pengetahuan mahasiwa dengan perilaku pencegahan "Hal ini dapat disimpulkan pula bahwa Tingkat pengetahuan tentang COVID-19 tidak mempunyai korelasi dengan perilaku pencegahan dan penularan. Simpulan penelitian ini adalah tingkat pengetahuan mahasiswa fakultas ekonomi tentang pencegahan dan penularan Corona Virus Disease di asrama putra dari 96 responden berada pada kategori tinggi. Para mahasiswa mengerti bagaimana cara untuk mencegah penularan Corona Virus Disease. Kondisi ini menjadi potensi dan kekuatan yang baik bagi pemerintah dalam program penanganan Corona Virus Disease. Namun upaya pencegahan dan pemantauan terhadap pemutusan penyebaran Corona Virus Disease masih harus terus dilakukan oleh berbagai pihak agar tidak terjadi penambahan jumlah kasus yang serius.
\end{abstract}

Kata Kunci: COVID-19, Remaja, Pengetahuan, Pencegahan 


\section{PENDAHULUAN}

Lembaga pendidikan yang berasrama, yang mayoritas adalah Fakultas Ekonomi, para mahasiswa ini, memiliki respon pengetahuan yang berbeda beda sebab dan akibat dari dampak penyebaran dan pencegahan COVID-19. Para pelajar yang tinggal di asrama berpotensi dalam penyebaran infeksi, memiliki tingkat pengetahuan tentang pencegahan dan penularan COVID-19 harus dipahami oleh setiap pelajar. Perilaku pencegahan dan penularan, dipengaruhi tingkat pengetahuan, dan mahasiswa yang mempunyai pengetahuan yang baik diharapkan mempunyai sikap yang baik agar pencegahan dan penyebaran dapat di antisipasi dan di minimalisiskan dari para pelajar kepada sesama pelajar, guru dan dosen tidak dapat terjadi.

Keadaan lingkungan di asrama putra rentan terhadap virus corona. Hal ini di karena kan satu ruangan kamar terdiri dari 3-4 orang .mahasiswa inside berjumlah 96, sehingga mudah sekali terinfeksi virus tersebut. Cenderung banyak sekali mahasiswa yang tinggal di luar kampus yang sering berinteraksi dengan anak inside asrama,sehingga mudah sekali membawa virus corona, tanpa diketahui. Oleh karena itu, belum banyak mahasiswa fakultas ekonomi yang belum mengetahui cara mencegah dan penularan virus tersebut. Penelitian ini dilakukan untuk mengetahui tingkat pengetahuan mahasiswa fakultas ekonomi Universitas Advent Indonesia tentang pencegahan dan penularan COVID-19 di asrama putra.

Hal ini sangat berpengaruh dalam kesehatan dan pendidikan.Hampir seluruhnya melalui daring atau belajar online, dari pendidikan tingkat awal sampai perkuliahan. Sempat disalah gunakan bahwa from home system dijadikan libur panjang oleh sebagian pekerja dan pelajar. Namun memberikan dampak buruk juga bagi pemilik usaha kecil hingga besar. Tidak hanya pemilik, karyawannya pun ikut menerima dirumahkan akibat perusahaan tempatnya bekerja tidak memperoleh pendapatan. Dibalik itu semua kesehatan tetap yang paling utama, walaupun sudah diberlakukannya sistem lockdown bagi sebagian wilayah tetapi tetap banyak warga ataupun masyarakat yang menyepelekan kondisi ini, terutama virus COVID-19.

Pengetahuan tentang COVID-19 juga penting untuk diketahui anak-anak usia 5-10 tahun dan remaja usia 10-19 tahun untuk orang dewasa tidak sulit untuk dijelaskan. Tetapi untuk anak-anak,dan remaja pandemi global ini masih sulit dicerna dan dipahami, bahkan untuk para remaja lebih banyak meyepelekan pandemic ini. Kurangnya pengetahuan, seperti lingkup keluarga,dan pergaulan. Itu sebabnya orang tua perlu melihat kedepan dan perlahan-lahan menjelaskan soal COVID-19 kepada anak -anak maupun remaja. Sehingga mengerti setidaknya sedikit pencegahan penularan secara mandiri. Meskipun harus selalu dibawah pengawasan orang dewasa. Pengetahuan adalah kemampuan untuk menerima, mempertahankan, dan menggunakan informasi, yang dipengaruhi oleh pengalaman dan keterampilan. Sebagian besar dari pengetahuan yang dimiliki seseorang berasal dari pendidikan baik formal dan informal, pengalaman pribadi maupun orang lain, lingkungan, serta media massa (Siltrakool,2012).

Sumber pengetahuan terkait COVID-19 didapatkan mahasiswa dari media social ,internet televisi, kementerian kesehatan, WHO dan informasi teman (Alzoubi, et al.,2020). Untuk para remaja yang dominan usianya 10-19 tahun terutama tak lepas dari ponsel tak heran para remaja dapat dengan mudah terpapar informasi tersebut. Ada sebahagian yang memproses informasi tersebut dengan meningkatkan mawas diri, ada juga yang jadi ketakutan atas pandemic yang menimpa beberapa Negara dengan korban yang begitu banyak. Tapi tidak dipungkiri banyak remaja yang menyepelekan virus ini.Mungkin ada beberapa yang kesulitan memahami apa yang dilihat diberita televisi atau informasi di internet mengenai virus COVID-19.

Terkait penularan, pencegahan, hingga dampak yang mematikan bisa terjadi. Saat remaja mengabaikan hal tersebut, justru mereka lebih cenderung ceroboh, tidak menjaga kebersihan, serta menjadi media penularan baru. Apalagi menimbulkan perasaan cemas, stres, dan sedih, orang tua harus turun tangan. Diskusi terbuka dapat membantu para remaja memahami, mengatasi, bahkan memberikan kontribusi positif bagi orang lain. menilai, peran pemuda yang milenial sangat penting ditengah pandemi COVID-19, terutama dalam memberikan informasi dan memberikan edukasi cara mencuci tangan menggunakan sabun dengan benar untuk mencegah penyebaran dan membawa hand sanitizer, menggunakan masker kemana pun kita pergi, menjaga jarak minimal 1 meter kepada orang-orang sekitarnya.(Hanifah,et al.,2020)

Peningkatan jumlah kasus corona terjadi dalam waktu singkat dan membutuhkan penanganan segera.virus corona dapat mudah menyebar dan menginfeksi siapa pun tanpa pandang usia. Virus ini dapat menular mudah melalui kontak dengan penderita. Hingga kini belum ada obat untuk menangani kasus infeksi virus corona atau COVID19 karena alasan inilah pemerintah di beberapa Negara memutuskan untuk menerapkan lockdown atau karantina. Beberapa negara yang telah 
menerapkan lockdown untuk mencegah penyebaran virus corona adalah China ,Spanyol ,Italia , dan Malaysia pemerintah Negara tersebut menutup akses fasilitas public dan transportasi. Warga dihimbau untuk tetap dirumah dan mengisolasi diri, dengan harapan virus tidak menyebar lebih luas (Perdana, 2020 ; kottasova, 2020)

Corona Virus Disease 2019 (COVID-19) adalah penyakit infeksi yang disebabkan oleh corona virus jenis baru yang ditemukan pada tahun 2019 yang selanjutnya disebut Severe Acute Respitatory Syndrome (SARS)-COV. Virus ini berukuran sangat kecil yang utamanya menginfeksi hewan termasuk diantaranya adalah kelelawar dan unta. Saat ini penyebaran dari manusia kemanusia menjadi sumber penularan utama sehingga penyebaran virus ini terjadi sangat agresif yang menyebabkan semua orang rentan terinfeksi. Penularan penyakit ini terjadi dari pasien positif COVID-19 melalui droplet yang keluar saat batuk dan bersin.( Han Y, 2020).

Penambahan jumlah kasus COVID-19 berlangsung cukup cepat dan sudah terjadi penyebaran antar Negara (Dong et al.,2020). Dilaporkan total kasus konfirmasi 414.179 dengan 18.440 kematian dimana kasus dilaporkan di 192 negara atau wilayah seperti Indonesia, Amerika dan beberapa Negara lainnya. Sudah ada beberapa petugas kesehatan yang dilaporkan terinfeksi (Kemenkes RI, 2020). Karena penularan COVID-19 berlangsung sangat cepat hingga hampir tak ada negara di dunia yang dapat memastikan diri terhindar dari virus corona (Widiyani, 2020). Penelitian ini bertujuan untuk mengetahui hubungan tingkat pengetahuan tentang pencegahan dan penularan COVID-19 dan aspek praktek dalam upaya pencegahan dan penularan COVID-19 di asrama putra.Lalu peneliti melakukan analisis untuk mengetahui hubungan antara kedua variabel dan menguji menggunakan uji chi square

\section{METODE PENELITIAN}

Dalam penelitian yang dilakukan, peneliti menggunakan metode penelitian korelatif untuk mengetahui hubungan antara variabel tanpa mempengaruhi dan memanipulasi variabel.Pada penelitian ini yang menjadi populasinya adalah mahasiswa Universitas Advent Indonesia fakultas ekonomi tinggal di asrama berjumlah 96 orang Pengumpulan data dilakukan dengan bantuan aplikasi Google Form yang akan diberikan ke mahasiswa fakultas ekonomi di asrama putra yang terdiri dari tingkat 1,2,3 hingga tingkat 4 . Teknik pengambilan sampling dalam penelitian ini adalah Total sampling, dengan pengambilan data menggunakan kuesioner yang dibagikan secara online untuk mahasiswa fakultas ekonomi yang bersedia ikut serta dalam penelitian ini dengan menyetujui informed consent, responden yang masuk dalam penelitian ini berjumlah 96 orang.

Instrument dalam penelitian ini menggunakan kuesioner mengenai konsep pengetahuan dan kuisioner aspek praktek dalam upaya pencegahan dan penularan COVID-19 yang diambil dari Penelitian Yodang Yodang Universitas Sembilan belas November Kolaka,Sulawesi Tenggara, Indonesia .Kedua kuesioner dengan nilai. aspek pengetahuan diukur dengan skala frekuensi verbal dimana responden memilih benar atau salah. Begitu pula dengan kuesioner praktek dimana memilih tidak pernah, jarang, kadang-kadang, dan selalu. Artikel ini telah melalui uji etik yang disetujui oleh KEPK FIK UNAI dengan No. 127/KEPK FIK.UNAI/EC/XI/20 pada 24 November 2020. Analisa data dengan menggunakan aplikasi statistical package for the social sciences (SPSS).

\section{HASIL PENELITIAN}

Berikut ini adalah hasil penelitian distribusi responden tingkat pengetahuan mahasiswa tentang Covid-19 yang tersaji dalam tabel-1 berikut penjabarannya

Tabel 1. Distribusi Responden Tingkat Pengetahuan Mahasiswa Tentang COVID-19 Pada Fakultas Ekonomi Di Asrama Putra Universitas Advent Indonesia

\begin{tabular}{lcc}
\hline \multicolumn{1}{c}{ Fakultas } & Frekuensi & Percentage (\%) \\
\hline akuntansi & 77 & 80.20 \\
Manajemen & 19 & 19.80 \\
Total & 96 & 100.00 \\
\hline
\end{tabular}

Berdasarkan Tabel 1 didapati bahwa responden jurusan akuntansi berjumlah 77 orang (80.20\%) sedangkan dari jurusan manajemen berjumlah 19 orang(19.80\%). untuk mengetahui tingkat pengetahuan maka dihitung nilai rata rata keseluruhan lalu diinterpretasikan berdasarkan skoring tingkat pengetahuan mulai dari pengetahuan kurang sampai kepada pengetahuan yang sangat baik.

Tabel 2. Tabel Frekuensi Responden Mahasiswa Universitas Advent Indonesia Fakultas Ekonomi

\begin{tabular}{lcc}
\hline \multicolumn{1}{r}{ Tingkat } & Frekuensi & Percentage (\%) \\
\hline I & 17 & 17.7 \\
II & 18 & 18.18 \\
III & 33 & 34.4 \\
\hline
\end{tabular}




\begin{tabular}{lcc}
\hline IV & 28 & 29.2 \\
Total & 96 & 100.00 \\
\hline
\end{tabular}

Berdasarkan Tabel 2 presentasi pengisi responden terbanyak adalah mahasiswa tingkat III sebanyak $34.4 \%$, disusul oleh tingkat IV sebanyak $29.2 \%$, lalu tingkat II sebanyak $18.18 \%$,dan terakhir adalah tingkat I sebanyak $17.7 \%$

Tabel 3. Presentasi Tingkat Pengetahuan Mahasiswa Tentang COVID-19 Pada Fakultas Ekonomi Di Asrama Putra Universitas Advent Indonesia Terhadap Penularan Virus COVID-19.

\begin{tabular}{lllll}
\hline $\begin{array}{l}\text { Tabel Tingkat } \\
\text { Pengetahuan } \\
\begin{array}{l}\text { Terhadap } \\
\text { Penularan } \\
\text { COVID-19 }\end{array}\end{array}$ & Freq Percent & & $\begin{array}{l}\text { Valid } \\
\text { Percent }\end{array}$ & $\begin{array}{l}\text { Cumulative } \\
\text { Percent }\end{array}$ \\
\hline Sangat baik & 45 & 46.9 & 46.9 & 46.9 \\
Baik & 36 & 37.5 & 37.5 & 84.4 \\
Biasa & 12 & 12.5 & 12.5 & 96.9 \\
Sangat buruk & 3 & 3.1 & 3.1 & 100.0 \\
Total & 96 & 100.0 & 100.0 & \\
\hline
\end{tabular}

Dalam tabel 3 diatas dapat dilihat frekuensi tingkat pengetahuan mahasiswa fakultas ekonomi di asrama putra menunjukkan bahwa sebagian besar mahasiswa memiliki Tingkat pengetahuan sangat baik tentang COVID-19 yaitu sebanyak 45\%. Dan yang memiliki tingkat pengetahuan baik ialah sebanyak 36\% mahasiswa. hanya $3 \%$ mahasiswa yang memiliki pengetahuan buruk tentang COVID19

Tabel 4. Presentasi Tingkat Pengetahuan Mahasiswa Tentang COVID-19 Pada Fakultas Ekonomi di Asrama Putra Universitas Advent Indonesia terhadap pencegahan virus COVID-19.

\begin{tabular}{lcccc}
\hline Valid & \multicolumn{5}{c}{ Frequency } & \multicolumn{3}{c}{$\begin{array}{c}\text { Valid } \\
\text { Percent }\end{array}$} & $\begin{array}{c}\text { Cumulative } \\
\text { Percent }\end{array}$ \\
\hline $\begin{array}{l}\text { Sangat } \\
\text { tinggi }\end{array}$ & 80 & 83.3 & 83.3 & 83.3 \\
Biasa & 16 & 16.7 & 16.7 & 100.0 \\
Total & 96 & 100.0 & 100.0 & \\
\hline
\end{tabular}

Dalam tabel 4 sebanyak $83 \%$ menunjukkan bahwa sebagian besar mahasiswa fakultas ekonomi di asrama puta memiliki kebiasaan yang sangat tinggi dengan pertanyaan "Isolasi dan perawatan orang yang terinfeksi virus COVID-19 adalah cara yang efektif untuk mengurangi penyebaran virus" dan "Pentingnya melaporkan ke tim kesehatan bila ada yang terduga untuk menghindari atau pencegahan virus COVID-19, dan sebagian mahasiswa fakultas ekonomi di asrama putra menunjukkan tingkat pengetahuan biasa sebanyak $16 \%$.dengan pertanyaan Hidung tersumbat, pilek dan bersin jarang terjadi pada orang yang terinfeksi virus corona (COVID19)". Kemudian "Mengkomsumsi atau kontak langsung dengan hewan liar akan mengakibatkan infeksi oleh virus COVID-19. Kemudian "Orang dengan COVID-2019 tidak dapat menginfeksi virus ke orang lain ketika tidak ada demam". Dan "Tidak perlu bagi anak-anak dan remaja untuk mengambil langkah-langkah untuk mencegah infeksi oleh virus COVID-19.

Tabel 5. Hubungan Mahasiswa Fakultas Ekonomi Yang Dilakukan Dalam Upaya Untuk Mencegah COVID-19 Di Asrama Putra Universitas Advent Indonesia.

\begin{tabular}{llll}
\hline $\begin{array}{l}\text { Tingkat } \\
\text { Pengetahuan }\end{array}$ & $\begin{array}{l}\text { Praktek Mahasiswa } \\
\text { Sangat } \\
\text { Tinggi }\end{array}$ & Biasa & Total \\
\hline Sangat baik & 38 & 7 & 45 \\
Baik & 30 & 6 & 36 \\
Biasa & 9 & 3 & 12 \\
Buruk & 3 & 0 & 3 \\
Total & 80 & 16 & 96 \\
\hline
\end{tabular}

Dalam tabel 5 kita dapat melihat mahasiswa yang memiliki pengetahuan dan praktek yang sangat baik sebesar $45 \%$, Dan pengetahuan dan praktek yang baik sebesar $36 \%$, pengetahuan yang biasa dan praktek sebesar $9 \%$, pengetahuan yang biasa dan praktek buruk hanya 0 .

Tabel 6. Chi-Square Tests

\begin{tabular}{llll}
\hline & Value & Df & $\begin{array}{l}\text { Asymp. } \\
\text { Sig. (2-sided) }\end{array}$ \\
\hline Pearson Chi-Square & $1.240^{\mathrm{a}}$ & 3 & .743 \\
Likelihood Ratio & 1.671 & 3 & .643 \\
$\begin{array}{l}\text { Linear-by-Linear } \\
\text { Association }\end{array}$ & .029 & 1 & .865 \\
N of Valid Cases & 96 & & \\
\hline
\end{tabular}

Berdasarkan tabel 6 terlihat nilai Asimp.Sig 0,743> 0,05 . Maka dapat disimpulkan bahwa " Tidak terdapat hubungan yang signifikan antara Tingkat pengetahuan mahasiwa dengan perilaku pencegahan ".Hal ini dapat disimpulkan pula bahwa Tingkat 
pengetahuan tentang COVID-19 tidak mempunyai korelasi dengan perilaku pencegahan dan penularan.

\section{PEMBAHASAN}

Pada tabel 1 menunjukan bahwa lebih banyak didominasi jurusan akuntansi sebanyak (80,2\%), dibandingkan jurusan manajemen, yaitu sebanyak $(19.80 \%)$ mahasiswa. Salah satu faktor internal yang mempengaruhi tingkat pengetahuan seseorang adalah tingkat pendidikan, semakin tinggi tingkat pendidikan seseorang maka semakin tinggi pula pengetahuan (Notoatmodjo,2010) tingkat pendidikan seseorang berpengaruh pada kemampuan berfikir, seseorang akan berfikir lebih rasional mampu menguraikan dalam menangkap informasi salah satunya dipengaruhi tingkat pendidikan. Salah satu factor yang mempengaruhi pendidikan adalah informasi, social, budaya dan lingkungan. Pengetahuan tidak hanya didapatkan dari jenjang pendidikan yang ditempuh namun juga didukung dari informasi yang diterima misalnya dari media masa, koran, majalah, internet, televisi. Motivasi juga mempengaruhi pengetahuan seseorang, karena akan meningkatkan rasa ingin tahu terhadap sesuatu, rasa ingin tahu yang semakin meningkat akan memotivasi seseorang untuk mencari sumber informasi.

Tabel 2 menunjukan bahwa pengisi responden terbanyak adalah mahasiswa tingkat 3 sebanyak $34.4 \%$ dan disusul oleh tingkat 4 sebanyak 29.2\% mahasiswa. Tabel 3 dapat dilihat frekuensi tingkat pengetahuan mahasiswa fakultas ekonomi di asrama putra sangat baik $46,9 \%$ hanya $3 \%$ mahasiswa yang memiliki pengetahuan buruk tentang COVID-19. Hal ini dikatakan oleh Ahmadi,(2013). bahwa Seseorang yang telah mengetahui tentang suatu informasi tertentu, maka dia akan mampu menentukan dan mengambil keputusan bagaimana dia harus menghadapinya.dengan kata lain, saat seseorang mempunyai informasi tentang COVID19, maka ia akan mampu untuk menentukan bagaimana dirinya harus berperilaku terhadap COVID-19 tersebut.

Perilaku yang baik dapat menjadi upaya pencegahan terhadap penularan covid 19 (Audria, 2019). Perilaku kesehatan dipengaruhi oleh banyak factor, diantaranya pengetahuan, persepsi, emosi, motivasi, dan lingkungan (Rahayu,2014). Bentuk perilaku yang ditunjukkan antara lain kepatuhan dalam menggunakan masker saat berada diluar rumah, mencuci tangan dengan sabun atau hand sanitizer secara sering,menghindari kerumunan dan menjaga social ataupun physical distancing.Cuci tangan adalah salah satu cara yang efektif untuk membunuh kuman,diketahui virus COVID-19 dapat menempel pada bagian tubuh terutama tangan yang menyentuh benda yang sudah tertular oleh droplet.Disampaikan oleh Kementerian Kesehatan bahwa75\% penularan virus covid adalah melalui percikan air ludah pada benda (kemenkes,2020).

Dalam tabel 4 sebanyak 83\% menunjukkan bahwa sebagian besar mahasiswa fakultas ekonomi di asrama puta memiliki kebiasaan yang sangat tinggi dengan pertanyaan "Isolasi dan perawatan orang yang terinfeksi virus COVID-19 adalah cara yang efektif untuk mengurangi penyebaran virus" dan "Pentingnya melaporkan ke tim kesehatan bila ada yang terduga untuk menghindari atau pencegahan virus COVID-19, dan sebagian mahasiswa fakultas ekonomi di asrama putra menunjukkan tingkat pengetahuan biasa sebanyak $16 \%$.dengan pertanyaan Hidung tersumbat, pilek dan bersin jarang terjadi pada orang yang terinfeksi virus corona (COVID19)". Kemudian "Mengkomsumsi atau kontak langsung dengan hewan liar akan mengakibatkan infeksi oleh virus COVID-19. Kemudian "Orang dengan COVID-2019 tidak dapat menginfeksi virus ke orang lain ketika tidak ada demam". Dan "Tidak perlu bagi anak-anak dan remaja untuk mengambil langkah-langkah untuk mencegah infeksi oleh virus COVID-19 peningkatan pengetahuan terkait dengan edukasi pencegahan penularan virus Covid 19 dan bahaya covid 19 . Pemerintah memberikan edukasi pada mahasiswa terkait protocol kesehatan saat bertemu dengan orang lain seperti selalu memakai masker, menjaga jarak minimal 1 meter, dan selalu cuci tangan menggunakan sabun (Mas'udi \& Winanti, 2020) Kepatuhan merupakan perilaku positif .Sebaliknya perilaku yang tidak baik akan meningkatkan jumlah kasus dan angka kematian akibat penularan COVID-19 (Simbolon,2020).

Dalam tabel 5 kita dapat melihat mahasiswa yang memiliki pengetahuan dan prakterk yang tinggi sebesar 45, pengetahuan yang sangat baik dan praktek yang biasa sebesar 7, pengetahuan yang baik dan praktek yang sangat tinggi sebesar 36, pengetahuan yang biasa dan praktek yang tinggi sebesar 9, pengetahuan yang biasa dan praktek yang biasa sebesar 3, pengetahuan yang buruk dan praktek yang sanagat tinggi sebesar 3 dan pengetahuan yang buruk dan praktek yang biasa sebesar 0. Perilaku Hidup Bersih dan Sehat adalah sekumpulan perilaku yang dipraktekkan atas dasar kesadaran sebagai hasil pembelajaran yang menjadikan seseorang atau keluarga mampu menolong dirinya sendiri di bidang kesehatan dan berperan aktif dalam mewujudkan kesehatan (Aulina 2018) Pemberian pendidikan kesehatan merupakan salah satu langkah untuk meningkatkan kesiapan masyarakat dalam menghadapi permasalahan di masa pandemic hal ini akan mempengaruhi pengetahuan dan sikap. 
Pengetahuan akan meningkat, dan mendorong sikap positif (Peng, et al., 2020). Hal ini menunjukkan dalam kehidupan sehari-hari mempengaruhi pengetahuan dan berdampak pada sikap pencegahan COVID-19 (Ssebuufu, et al., 2020).

\section{KESIMPULAN}

Berdasarkan hasil penelitian ini, menunjukkan pengetahuan mahasiswa universitas Advent Indonesia fakultas ekonomi tentang pencegahan dan penularan COVID-19 di asrama putra dari 96 responden berada pada kategori tinggi dan perilaku baik. Karena Bagi kampus Universitas Advent Indonesia diharapkan memberikan penyuluhan tentang bahaya virus COVID-19 secara berkala kepada siswa sehingga lebih memahami tentang virus COVID-19 dan dampak yang diakibatkan. Selain mempunyai peranan yang sangat besar dalam upaya pencegahan virus COVID-19 di semua kalangan dan mematuhi kebijakan aturan yang dikeluarkan oleh pemerintah, sehingga dapat memutuskan rantai penyebaran virus COVID19.para mahasiswa mengerti bagaimana cara untuk mencegah penularan COVID-19 Kondisi ini menjadi potensi dan kekuatan yang baik bagi pemerintah dalam program penanganan COVID-19 ini.Namun demikian,upaya pencegahan dan pemantauan terhadap pemutusan penyebaran covid19 masih harus terus dilakukan oleh berbagai pihak agar tidak terjadi penambahan jumlah kasus yang serius.

\section{DAFTAR PUSTAKA}

Peng, Y. et al., 2020. Knowledge, Attitude and Practice Associated with COVID-19 among. Research square

Ssebuufu, R. et al., 2020. Awareness, knowledge, attitude and practice towards measures for prevention of the spread of COVID-19 in the Ugandans: A nationwide online cross-sectional Survey. medRxiv

Aulina, Choirun Nisak. 2018. Peningkatan Kesehatan Anak Usia Dini dengan Penerapan Perilaku Hidup Bersih dan Sehat (PHBS) di TK Kecamatan Candi Sidoarjo.” AKSIOLOGIYA : Jurnal Pengabdian Kepada Masyarakat3 (1): 50. https://doi.org/10.30651/aks.v3i1.1480

Notoatmodjo, S. (2010).Ilmu Perilaku Kesehatan,Jakarta : Rineka Cipta. Jakarta

Kementerian kesehatan RI. (2020). Pedoman Pencegahan dan Pengendalian
Coronavirus Disease (COVID-19). 18 April 2020

Mas'udi, W. \& Winanti, P. S., 2020. Tata Kelola Penanganan Covid 19 di Indonesia. In: s.l.: Fakultas Ilmu Sosial dan Ilmu Politik Universitas Gajah Mada.

Demsa Simbolon (2020). Kepatuhan Civitas Akademik Poltekkes Kemenkes Bengkulu Mengikuti Perauran Pemerintah Dalam Pencegahan penularan Virus COVID-19: http://sinta.ristekbrin.go.id/covid/penelitian/ detail/403

Ahmadi (2013).Kesehatan Masyarakat,teori dan aplikasi.

Jakarta: Raja Grafindo

Audri Okta AWD (2019) Hubungan Pengetahuan dan Sikap Terhadap Perilaku Cuci Tangan pada Masyarakat Kelurahan Pegirian,Jurnal Promkes: The Indonesian Journal of Health Promotion And Health Education, vol 7 No, 1 (2019) 1-11DOI : 10.20473/jpk.V7.11.2019.1-11

Widiyani, R. (2020). Latar Belakang Virus Corona, perkembangan hingga isu terkini. Retrieved from detik News

No, V., \& Mona, N. (2020). Konsep Isolasi Dalam Jaringan Sosial Untuk Meminimalisasi Efek Contagious (Kasus Penyebaran Virus Corona Di Indonesia). Jurnal Sosial Humaniora Terapan, 2(2), 117-125.

https://doi.org/10.7454/jsht.v2i2.86

Kementerian kesehatan RI (2020), situasi Terkini Perkembangan Coronavirus Disease (COVID-19) Media informasi Resmi Terkini Penyakit infeksi Emerging, http://covid19.kemenkes.go.id

Kementerian Kesehatan RI (2020). Pedoman pencegahan dan pengendalian Coronavirus Disease (COVID-19) 18 April 2020

Alzoubi, H. et al., 2020. Covid 19 knowledge, Attitude and Practiceamong Medical and Non-Medical University Students in Jordan. Journal Of Pure and Applied Microbiology.

Moudy, Jesica \& Syakurah, Rizma. (2020). Pengetahuan terkait Usaha Pencegahan Coronavirus Disease (COVID-19) di Indonesia. HIGEIA (Journal of Public 
Health Research and Development). 4. 333346. 10.15294/higeia.v4i3.37844.

Han Y, Yang H (2020), The Transmission and Diagnosis of 2019 novel coronavirus infection disease(COVID- 19). Chinese perspective. J Med Virol. Published online March 6 DOI:10.1002/jmv.25749 